\title{
Growth/Differentiation Factor 3
}

National Cancer Institute

\section{Source}

National Cancer Institute. Growth/Differentiation Factor 3. NCI Thesaurus. Code C101651.

Growth/differentiation factor 3 (364 aa, $\sim 41 \mathrm{kDa}$ ) is encoded by the human GDF3 gene.

This protein is involved in the modulation of both cell growth and differentiation. 